\title{
Knowledge of Rural and Urban Homemakers in Indigenous Resource Management Practices
}

\author{
Shipra Sood and Avinash Sharma \\ Department of Family Resource Management, CSK Himachal Pradesh Krishi Vishvavidyalaya, \\ Palampur 176 062, Himachal Pradesh, India \\ E-mail: sood_shipra@rediffmail.com
}

KEYWORDS Indigenous Knowledge. Resource Management. Management Practices

\begin{abstract}
The study conducted on 120 rural and urban homemakers in two randomly selected panchayat wards and two municipal council wards of district Kangra of Himachal Pradesh revealed their knowledge regarding indigenous resource management practices. Results showed that knowledge levels vary among rural and urban homemakers which were tested with Z- test at 5 percent level of significance. There was significant difference among rural and urban families for indigenous practices for drying grain before storage, grain storage equipment, potato storage in basket, disposal of waste water in household drain, disposal of degradable waste, protecting clothes from insects, spraying medicine for flies, treatment of minor wounds and burns and use of medicine for boils and hypothesis was rejected for these practices but in case of stomach ache treatments the difference was non significant.
\end{abstract}

\section{INTRODUCTION}

Indigenous knowledge is the sum total of information or practices that are based on people's accumulated experiences. The dictionary meaning of indigenous refers to occurring or living naturally in a specific area such as native plants or animals. Warren (1989) defined indigenous knowledge as local knowledge which is unique to a given culture or society. Technically, indigenous knowledge has been defined by Basanta (1990) as knowledge originated in and characterizing a particular community, region or country with quantum and context of indigenous knowledge varying across space and changing over time. In our country, indigenous practices of resource management have always been used and are still followed, because it is supposed that these practices are useful in control of wastage of resources in the household. In the recent past, the indigenous technical knowledge reservoir is disappearing very fast and there is an urgent need to explore and document it.

Himachal Pradesh is a culturally rich state in terms of indigenous resource management practices in which families of rural and urban strata vary greatly. Their documentation is of paramount importance in order to understand their scientific rationale. Hence the present study was undertaken with an objective to identify and document the existing indigenous resource management practices of rural and urban households.

\section{MATERIALS AND METHODS}

The study was carried out in Kangra district of Himachal Pradesh with a sample size of 120 respondents as shown in Table 1. A three stage random sampling technique was adopted. From the two randomly selected blocks four municipal wards and four panchayat wards were selected randomly. With the help of proportional allocation method sixty respondents each were selected from rural and urban areas. The data were collected by survey method for the month of FebruaryMarch 2004. An interview schedule was structured to record data on prevalent indigenous practices in management of food, grain storage structures, waste management and management of diseases.

Hypothesis: Indigenous resource management practices of rural and urban families do not vary significantly.

Table 1: Distribution of sample respondents in the study area

\begin{tabular}{lcc}
\hline S. Name of & $\begin{array}{c}\text { Total number } \\
\text { of households }\end{array}$ & $\begin{array}{c}\text { Number of } \\
\text { respondent }\end{array}$ \\
No. selected area & 80 & 17 \\
1. Panchayat Wards & 40 & 9 \\
$\quad$ Bundla & 70 & 15 \\
$\quad$ Chimbalhaar & 90 & 19 \\
$\quad$ Pathiar & & \\
$\quad$ Malan & 120 & 18 \\
2. Municipal Wards & 129 & 15 \\
$\quad$ Janglat & 128 & 15 \\
$\quad$ Vidyarthian & 110 & 12 \\
$\quad$ Sarotri & & \\
$\quad$ Radha Krishna & &
\end{tabular}


Z- test was applied to find out the significance of difference between rural and urban families in case of indigenous resource management practices at 5 per cent level of significance.

\section{RESULTS AND DISCUSSIONS}

\section{General Information}

The distribution of the families according to their socio-economic profile is shown in table 2. The family type reveals that majority of the both rural and urban families $(56.67 \%$ \& $81.67 \%$ respectively) belong to nuclear families. The size of the family depicts that in rural area 51.67 percent had 5-6 family members whereas in urban area majority $(65.00 \%)$ had 3-4 family members.

The land holding profile of the families exhibits that maximum rural families $(71.66 \%)$ had land holding upto 12.5 kanals but 38 (63.33\%) urban families were landless. In rural areas, average family income was Rs. 7, 346 per month where as in urban area it was comparatively higher i.e. Rs 11,265 per month from all sources.

Table 2: General information of the respondent

\begin{tabular}{lcc}
\hline S. Characteristics & Rural & Urban \\
No. & & \\
\hline 1 Type of Family & & \\
$\quad$ Nuclear & $34(56.67)$ & $49(81.67)$ \\
$\quad$ Joint & $26(43.33)$ & $11(18.33)$ \\
2 Family Size (Members) & & \\
$\quad$ Upto 2 & - & $5(8.33)$ \\
$\quad$ 4-Mar & $25(41.67)$ & $39(65.00)$ \\
$\quad$ 6-May & $31(51.67)$ & $16(26.67)$ \\
$\quad$ Above 7 & $4(6.66)$ & - \\
3 Land Holding (Kanals) & & \\
$\quad$ Landless & $6(10.00)$ & $38(63.33)$ \\
$\quad$ Upto 12.5 & $43(71.66)$ & $19(31.66)$ \\
12.5-25.00 & $10(16.67)$ & $1(1.67)$ \\
25.00-37.5 & $--67)$ & $1(1.67)$ \\
37.5-50.00 & $1(1.67)$ & $1(1.67)$ \\
4 Average monthly & 7346 & 11265 \\
$\quad$ Income (Rs) & & \\
$\quad$ & &
\end{tabular}

\section{Storage Practices}

The differences among rural and urban households regarding indigenous resource management practices showed that majority of rural families $(90.00 \%)$ dry grain before storage whereas such urban families were very less in number $(3.33 \%)$. Rural homemakers used local Plant i.e. Barray leaves for protecting grain from insects but in Dronagiri, plant parts like leaves of Toona hexandra were used for protecting grain from insects as studied by Arya (2002). Regarding the grain storage equipment, majority of urban $(73.33 \%)$ families used stainless steel containers and rural users were 3.33 per cent. 68.33 per cent rural and 23.33 per cent urban families used aluminium containers. Pedu was also used by rural families $(18.33 \%)$ for grain storage. Bhople and Darbha (2000) reported the use of gunny bags (96.67\%), metal bins (54.67\%) for storage of food grains in Maharashtra.

For the storage of potato, majority urban (93.33\%) families used basket and such rural families were comparatively low (16.67\%).

\section{Waste Management Practices}

In 63.33 per cent urban households, wastewater went to house drain and maximum rural families disposed it directly to kitchen garden $(8.33 \%)$. Regarding disposal of degradable household waste, maximum (95.00\%) urban families used municipal dustbin but rural families do not use area dustbin. Majority of rural families (93.33\%) fed degradable waste to cows and other animals.

\section{Use of Insecticides}

For protecting clothes from insects all urban families dry clothes before storing but such rural families were 75 per cent. Red dried chillies were kept in woolen clothes to keep away silver fish. Almost all urban families (98.33\%) used naphthalene balls in clothes and rural were comparatively less (78.33\%). For getting rid of flies most of rural (70.00\%) and urban (36.67\%) families spray insecticide. Wheat flour was used to control ants in rural families. For mosquitoes, fumes of dung cakes were used.

\section{Management of Diseases}

In case of minor wounds, turmeric in hot oil was used in both rural $(81.67 \%)$ and urban $(43.33 \%)$ areas. Antiseptic liquid was also used in 23.33 percent rural and 55.00 percent urban families. Ice was used for minor burns by 55.00 per cent rural and 90.00 per cent urban families. Treatment of boils was also done with medicine in rural $(38.33 \%)$ and urban (65.00\%) families. Gulgul leaves were tied on chest for treating cold and cough.

For treating stomach ache omum were used by rural and urban families i.e. 63.33 and 78.33 per 
Table 3: Distribution of families according to indigenous resource management practices

\begin{tabular}{|c|c|c|c|c|}
\hline $\begin{array}{l}\text { S. Statement } \\
\text { No. }\end{array}$ & $\begin{array}{l}\text { Rural } \\
N=60\end{array}$ & $\begin{array}{r}\text { Urban } \\
N=60\end{array}$ & Z-cal & Significance \\
\hline $\begin{array}{l}\text { 1. Grain Storage Management } \\
\text { a. Drying grain before storage } \\
\text { b. Keeping barray leaves }\end{array}$ & \multicolumn{4}{|c|}{ 1. Grain Storage Management } \\
\hline \multicolumn{5}{|l|}{ 2. Grain Storage Equipment } \\
\hline a. Pedu & $11(18.33)$ & - & - & - \\
\hline b. Stainless steel & $2(3.33)$ & $44(73.33)$ & -2.1187 & NS \\
\hline c. Aluminium & $41(68.33)$ & $14(23.33)$ & 2.9354 & $\mathrm{~S}$ \\
\hline 3. Potato storage in basket & $10(16.67)$ & $56(93.33)$ & -6.4265 & $\mathrm{~S}$ \\
\hline 4. Disposal of wastewater in House drain & $5(8.33)$ & $38(63.33)$ & -2.3348 & $\mathrm{~S}$ \\
\hline \multicolumn{5}{|l|}{ 5. Disposal of Degradable Waste } \\
\hline a. Thrown in dustbin & & $57(95.00)$ & - & - \\
\hline b. Given to cow & $56(93.33)$ & $1(1.67)$ & 3.2979 & $\mathrm{~S}$ \\
\hline \multicolumn{5}{|l|}{ 6. Protecting Clothes from Insects } \\
\hline a. Keeping naphthalene balls & $47(78.33)$ & $59(98.33)$ & -3.3321 & $\mathrm{~S}$ \\
\hline b. Properly drying & $45(75.00)$ & $60(100.00)$ & -3.3087 & $\mathrm{~S}$ \\
\hline 7. Spraying insecticide for flies & $42(70.00)$ & $22(36.67)$ & 2.5709 & $\mathrm{~S}$ \\
\hline \multicolumn{5}{|l|}{ 8. Treatment of Minor Wounds } \\
\hline a. Turmeric mixed in hot oil & $49(81.67)$ & $26(43.33)$ & 3.3976 & $\mathrm{~S}$ \\
\hline b. Antiseptic liquid & $14(23.33)$ & $33(55.00)$ & -1.9935 & $\mathrm{~S}$ \\
\hline 9. Using ice for minor wounds & $33(55.00)$ & $54(90.00)$ & -3.7484 & $\mathrm{~S}$ \\
\hline 10. Using medicine for boils & $23(38.33)$ & $39(65.00)$ & -2.0393 & $\mathrm{~S}$ \\
\hline \multicolumn{5}{|l|}{ 11. Stomach Ache } \\
\hline a. Omum & $38(63.33)$ & $47(78.33)$ & -1.5252 & NS \\
\hline b. Aniseed & $27(45.00)$ & $24(40.00)$ & 0.3604 & NS \\
\hline 12. Herbal concoction for cough \& cold & $41(68.33)$ & $43(71.67)$ & -0.3334 & NS \\
\hline
\end{tabular}

Multiple responses. Tabulated Z- value $=1.96 \quad$ Note: Figures in parentheses indicate percentages to total household

cent respectively. Onion and mint juice was used for curing vomiting. 45.00 per cent rural and 40.00 percent urban families also used aniseeds. Herbal concoction using different medicinal plants was used by rural (68.33\%) and urban (71.67\%) families for cough and cold. It showed that people were leaving traditional systems and moving towards modernization. It was also confirmed by Farooquee et al. (1999) that traditional specializa-tions of indigenous people were breaking down because of value addition and impact of modernization.

\section{Hypothesis Testing}

Indigenous resource management practices of rural and urban families do not vary significantly. Applying Z-test at 5 per cent level of significance tested the hypothesis. The results showed that the difference among rural and urban families for indigenous practices was significant for drying grain before storage, grain storage equipment, potato storage in basket, disposal of waste water in household drain, disposal of degradable waste, protecting clothes from insects, spraying insecticide for flies, treatment of minor wound and burns and use of medicine for boils which clearly indicate that hypothesis was rejected for these practices and for stomach ache treatments hypothesis was accepted (Table 3 ).

\section{CONCLUSION}

The indigenous knowledge of homemakers in both rural and urban areas regarding the different aspects of resource management vary significantly except practices for stomach ache like using aniseed, omum and herbal concoction.

\section{REFERENCES}

Arya KR 2002. Traditional uses of some common plants in indigenous folklore of Dronagiri. Indian Journal of Traditional Knowledge, 1: 59-71.

Basanta R 1990. Documentation of indigenous knowledge in Gujarat agriculture. Paper Presented in International Workshop on Sustainability through Farmers Involvement in Technology Generation and Diffusion in Indian Society of Agronomy, New Delhi, 9 Feb. 1990.

Bhople RS, Darbha S 2000. Indigenous grain storage practices adopted in rural households. Agricultural Extension Review, 12: 26-29.

Farooquee NA, Annpurna N, Nautyal A 1999. Traditional knowledge and practices of Bhotiya pastoralists of Kumaon Himalaya. International Journal of Sustainable Development and World Ecology, 6: 60-67.

Warren DM 1989. Indigenous Knowledge- a definition. SKARD News, 1: 5 